\title{
Recent trends in population size and distribution of Ring-billed and California gulls in the western United States
}

\author{
Robert H. Doster ${ }^{1,{ }^{*}}$ ANd W. David Shuford ${ }^{2}$
}

\begin{abstract}
The breeding ranges of the Ring-billed Gull (Larus delawarensis) and California Gull (L. californicus) overlap broadly in the interior of western North America, where their populations have been increasing since the early 20th century. This trend has been attributed to the gulls' exploitation of new nesting sites at reservoirs and expanded opportunities for foraging at landfills and irrigated agricultural lands, but it might also reflect, in part, a rebound following declines from persecution and loss of historic wetland habitats. Here we update the population status of both species with data from broad-scale surveys of colonies conducted in 11 western states from 2009 to 2011 as part of the Western Colonial Waterbird Survey and surveys from a few coastal colonies during that period. We compare these results with data from the West in the late 1970 s to early 1980s. We estimate a minimum of 87,995 Ringbilled and 334,824 California gulls were breeding in the 11 western states from 2009 to 2011. Although recent estimates are higher than those from about 30 years prior, differences in study methods, assumptions, and environmental conditions make comparisons between the two periods difficult. It is clear, however, that the ranges of the two species have expanded south or west: slightly for the Ring-billed Gull and modestly for the California Gull, particularly with its colonization of the San Francisco Bay estuary followed by 30 years of exponential growth. Some new southern colonies, however, have been small, ephemeral, or have had poor reproductive success. These gull species are, of course, adapted to the periodic droughts that occur in the West, but there are limits to their adaptability. Thus, their populations may be affected as human manipulation of water systems and changing weather and climatic conditions increase the frequency of desiccation of foraging habitats and of predators' access to nesting islands. The challenge ahead will be to monitor gulls throughout the West in the context of continuing human alteration of the environment and both short-term fluctuations and long-term changes in climate. Likewise, it will be difficult to manage gull numbers regionally and locally where human food sources support large concentrations of gulls to the detriment of other nesting waterbirds and shorebirds.
\end{abstract}

Keywords: changing distribution, climate conditions, colonial nesting, drought effects, monitoring, population trends

T he Ring-billed Gull (Larus delawarensis) and California Gull (L. californicus) breed broadly but locally in the interior of the western United States. Overall, the Ring-billed Gull is more widespread, breeding across the northern United States and southern Canada (Pollet et al. 2012), whereas the California Gull is restricted mainly to the Columbia and Klamath river basins, Intermountain West, and northern prairies of the western United States and southern Canada (Winkler 1996). Both species also breed in limited areas on the Pacific coast, but there the only substantial population of either species is of the California Gull in San Francisco Bay (Strong et al. 2004, Burns et al. 2018).

From the 1840 s to 1920 s, numbers of the Ring-billed Gull declined and its range retracted-mainly in eastern regions-in response to human persecution (plumage for the millinery trade, eggs for food, and encroachment on nesting habitat; Pollet et al. 2012). Since then, its numbers have increased greatly and the species has reoccupied its former range. Historical changes to California Gull populations were less severe,

Full citation: Doster, R. H., and Shuford, W. D. 2018. Recent trends in population size and distribution of Ring-billed and California gulls in the western United States, in Trends and traditions: Avifaunal change in western North America (W. D. Shuford, R. E. Gill Jr., and C. M. Handel, eds.), pp. 161-179. Studies of Western Birds 3. Western Field Ornithologists, Camarillo, CA; doi 10.21199/SWB3.8.

${ }^{1}$ U.S. Fish and Wildlife Service, Migratory Bird Program, 2800 Cottage Way, Sacramento, California 95825, ${ }^{2}$ Point Blue Conservation Science, 3820 Cypress Drive \# 11, Petaluma, California 94954; *corresponding author: rob_doster@fws.gov 
though numbers likely were reduced by drainage of wetlands, human disturbance, and, locally, by commercial egg collecting (Winkler and Shuford 1988, Winkler 1996). Increases of both species' populations in the western United States in recent decades reflect the gulls' exploitation of landscape changes accompanying an expanding human population, including increased opportunities to forage at landfills and in extensive areas of irrigated agriculture and to nest at new sites at reservoirs and other impoundments (Winkler 1996, Pollet et al. 2012).

Conover (1983) reviewed the status of these two gull species to assess changes in their distribution and abundance across the western United States from $\sim 1930$ to the early 1980s. The reported substantial increase in the number of new colonies and abundance of both species over this 50 -year period is clouded, however, by various methodological shortcomings (Shuford and Ryan 2000:159-160). Subsequently reviews of the status of one or both of these species for individual states or large colonies in the West have been published (Findholt 1986a, b, Paul et al. 1990, Yochem et al. 1991, Shuford and Ryan 2000, Strong et al. 2004, Shuford 2010, 2014 , Shuford and Henderson 2010, Burns et al. 2018). Comparing trends over time, however, is difficult because few of these studies are based on data collected annually, or at longer intervals, by consistent standardized methods.

Here we report the results of a relatively comprehensive survey of breeding colonies of the Ring-billed and California gulls in the western United States conducted from 2009 to 2011, primarily as part of the Western Colonial Waterbird Survey (WCWS; www.fws.gov/mountain-prairie/ migbirds/species/birds/western_ colonial/), which spanned 11 western states and addressed 19 species. We supplement these results with data from surveys of the few coastal colonies of these gull species in the West. We also discuss patterns and potential causes of recent changes in the gulls' breeding distribution and trends in abundance, including the influence of drought and a changing climate. Finally, we make recommendations for future monitoring of gull distribution and abundance and highlight key issues for managing these gulls.

\section{STUDY AREA AND METHODS}

\section{Geography and Climate Conditions}

Surveys of gull colonies under the WCWS encompassed 11 western states: Washington, Oregon,
California, Idaho, Nevada, Montana, Wyoming, Utah, Colorado, Arizona, and New Mexico. Because of the census of gull colonies in coastal Washington, Oregon, and California in 2006 and 2007 , our more recent 11 -state effort did not survey gull colonies in coastal areas (Seto 2008). Still, to ensure complete coverage of the two gull species in the three coastal states, and hence throughout the entire 11-state region, we compiled data on coastal colonies recorded as part of other survey efforts, including those of Bird Research Northwest, San Francisco Bay Bird Observatory, and Point Blue Conservation Science (all unpubl. data).

Local climate patterns and the availability of surface water were highly variable across the three years of gull surveys, 2009-2011. Most of the West experienced abnormally dry to severe drought conditions in mid-April, when gulls typically are initiating nesting, in both 2009 and 2010, but not during the same time in 2011, following a wet winter (Figure 1; www.droughtmonitor.unl.edu).

\section{SURVEY MeTHODS}

U.S. Fish and Wildlife Service coordinated the overall 11-state effort, but the staff or volunteers of state agencies or nonprofit organizations coordinated or conducted surveys in individual states. Because the two species of gulls are ground nesters, observers surveying colonies followed the protocols appropriate for each species according to the WCWS (Jones 2008). Depending on local site conditions, various constraints (logistical, financial, time), or coordinators' preferences, observers made direct counts of active nests (adult on nest, or eggs or young visible), counts of adults or nests from aerial photographs, or ground- or boat-based counts or estimates of adults. Visual observations from an airplane were sometimes used to document the lack of nesting at a site, but not to count nests or adults. Coordinators selected aerial surveys for some large colonies, when colonies were not easily accessible by other means, or when censusing multiple colonies over a broad geographic area within a limited time. Surveys by air were usually from a fixed-wing aircraft, rarely from a helicopter.

When they had the time and were safely able to enter the colony with minimal effects on reproductive activity, observers counted the total number of nests. Observers often used temporary markers (e.g., flagging, tempera paint) to keep track of counted nests. To minimize effects on nesting gulls, observers entered colonies to count only when the sky was clear and the ambient 

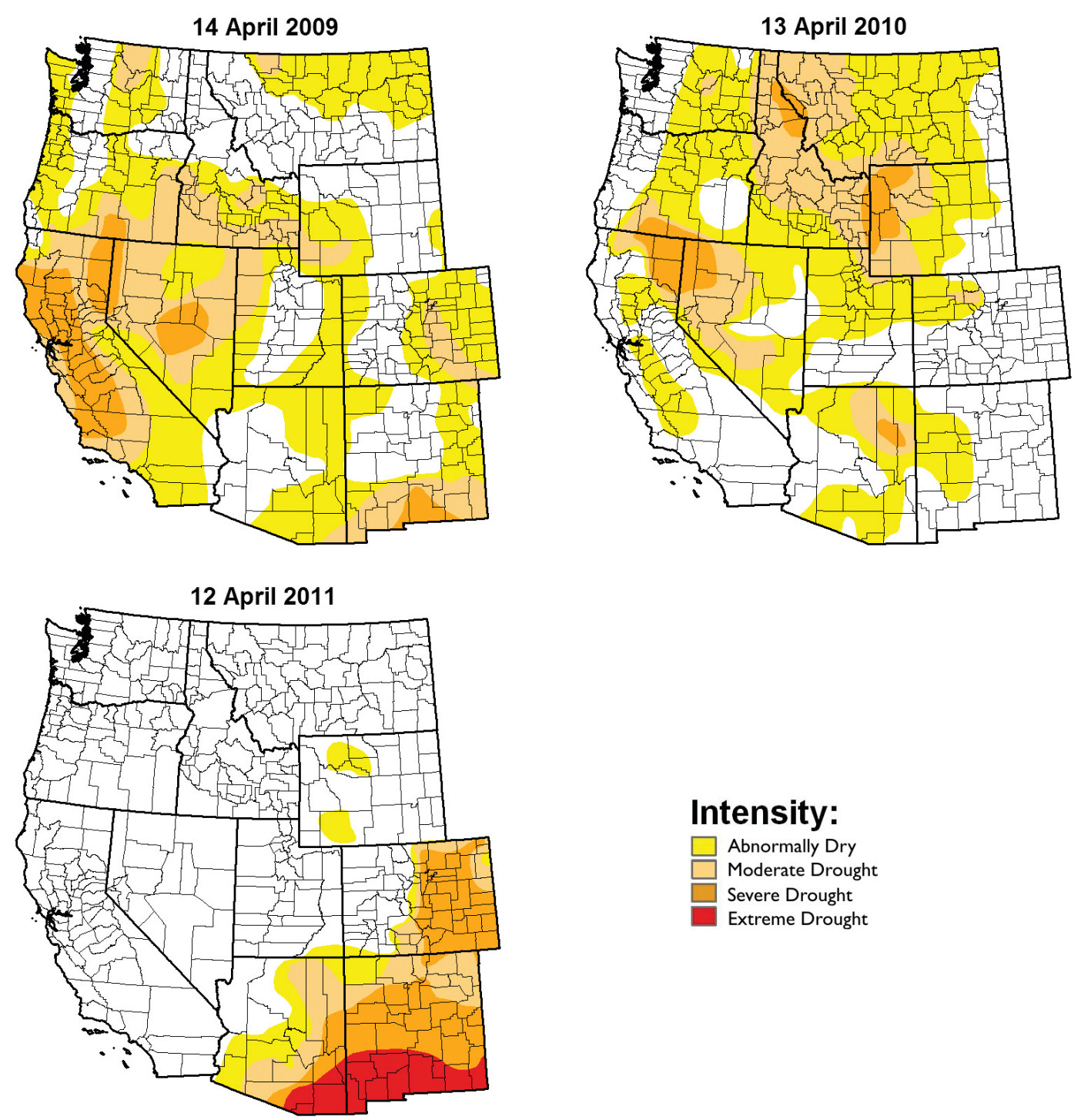

FIGURE 1. Broad-scale patterns of drought intensity in the western United States in mid-April, when gulls begin nesting, 2009-2011. Images and legend categories from www.droughtmonitor.unl.edu.

temperature $<27{ }^{\circ} \mathrm{C}$, or overcast with ambient temperature $<32{ }^{\circ} \mathrm{C}$, wind chill was not $<18{ }^{\circ} \mathrm{C}$, and there was no precipitation or threat of precipitation. Observers sometimes counted nests from the perimeter of a colony (e.g., from a boat) when entering the colony or flushing nesting birds was not an option or not necessary.

Surveys took place primarily from mid-May to mid-June each year, and, when possible, were timed to coincide with the colony's peak number of nests (typically during the mid- to late incubation period). As colonies can shift locations or change in size with fluctuating climatic conditions, water levels, and island availability, ideally all surveys should have been conducted in a single year, for an estimate of the total population of breeding adults. Although not all colonies were counted in a single year, most were counted in 2009. At sites surveyed in more than one year, we used the 2009 count, or the count from the year closest to 2009 when no count was conducted in 2009. This rule applied for sites that were surveyed in multiple years regardless of the year of the highest count. In the rare cases when a count was incomplete in the year initially selected we opted for a complete over an incomplete count. 
All colonies in Washington, Oregon, California, and Idaho were surveyed in 2009, as were most in Nevada and Wyoming. Collectively, the sites surveyed in 2009 accounted for the majority of the gulls from which we estimated the total nesting population for both species.

\section{ESTIMATES OF BREEDING ADULTS}

Depending on the survey method, we estimated the number of breeding gulls in two ways. For direct nest counts, we assumed that each active nest was equivalent to two breeding adults. In cases where only the number of adults at active colonies was counted or estimated, we used a correction factor to account for those birds that were away from the colony at the time of the survey. Specifically, we adjusted adult counts upward using the ratio of adults sitting on nests to total adults counted on oblique-angle aerial photos of plots at three colonies along the Columbia River in Washington and Oregon (Bird Research Northwest unpubl. data). For the Ring-billed Gull, counts were from Island 20 in 2008 and 2010 and Three Mile Canyon Island in 2008 and 2009; for the California Gull, counts were from Island 20 in 2008 and 2010 and Miller Rocks in 2007 and 2009. For each species, the correction factor was an average of the ratio of nests to total adults for the four counts available. Thus we estimated the number of nests as 0.706 of the number of adults counted for the Ring-billed Gull and 0.703 for the California Gull, then, as above, doubled the nest count to estimate total breeding adults. Surveys at Great Salt Lake were mostly from aerial photographs taken at 15 sites in 2010 (John Neill pers. comm.). For 14 of these, the images were of a resolution high enough that most adults sitting on nests could be distinguished from loafing gulls (nest counts for Gunnison and Egg islands were minima), but for Hat Island the resolution was good enough only for a count of total adults. For that site, we derived a correction factor of 0.715 by calculating the average of the ratio of nests to total adults for the 14 sites for which those data were available. These ratios for colonies in Washington and Utah from 2007 to 2010 are very similar to those of 0.71 and 0.72 for the respective species derived from comparable counts of nests and adults at Clear Lake National Wildlife Refuge (NWR), California, in 1994 (Shuford and Ryan 2000). Regardless of the method for estimating breeding adults, we made no attempt to account for nonbreeding individuals, owing to the difficulty (if not impossibility) of doing so.

\section{COMPARISONS TO PRIOR DATA}

Conover (1983) compiled estimates of the numbers of breeding Ring-billed and California gulls for 11 of the western United States for the period 1976-1982, but these are not the same 11 states surveyed from 2009 to 2011. Conover's summary included data from North and South Dakota (not included in our inventory) but not from Arizona and New Mexico, two states we included but in which no colonies were found. Thus, to enable a comparison of gull numbers for the two periods for the same suite of states, we adjusted Conover's numbers by excluding the 13,527 California Gulls and 21,911 Ring-billed Gulls estimated for the Dakotas from the overall estimates of 276,000 and 106,000 for the two species, respectively. To calculate these Dakota totals, we summed the numbers for each species for the active colonies in the two states combined (Conover 1983, Appendix 2): 10 and 15 active colonies for the California and Ring-billed, respectively. When there was a numerical estimate for more than one year, we used the most recent one; if there was a numerical estimate for one year and a determination of "breeding" for a more recent year we used the numerical estimate. When there was no numerical estimate at all but just a determination of "breeding," we used the mean colony size Conover used when he estimated the size of all such colonies in each state when compiling his 11-state total, i.e., 3455 and 1867 for the California and Ring-billed, respectively. When a colony was identified as both "breeding" and "deserted" in the same year, we used the mean colony size for "breeding," assuming the colony could have been active initially, then deserted later in the season. If one of these determinations was for an unknown year and the other for a specified year, we used the latter. If both determinations were from unknown years we used the one with the latest referenced source, assuming that it reflected information from the most recent year. Knowing that colonies can come and go in relatively short periods depending on fluctuating environmental or other factors (see below), we refrained from comparing the number of colonies active across the 9 states common to each period because of the period of the earlier compilation (7 years) being longer than the period of recent surveys (3 years), in which the majority of gulls and colonies were surveyed in one year.

We also compared colony-survey data with trends for the Ring-billed and California gulls derived from the North American Breeding Bird Survey (BBS; Sauer et al. 2014). We considered 
the trends reported for states, regions, and surveywide adequate for analysis if they had one of the two highest credibility rankings (flagged blue or yellow), and we excluded those categorized as having an important deficiency (flagged red; www. mbr-pwrc.usgs.gov/bbs/credhm09.html).

\section{MAPPING}

We mapped the distribution and relative size of gull colonies from 2009 to 2011 with ArcMap version 10.2.2 (ESRI); values for categories of relative abundance were based on natural breaks in the data. Given that many islands on which gulls nest inland are ephemeral, their size or availability for nesting changing from year to year, we generally considered a colony as the whole of a site such as a lake or wetland for purposes of mapping or tabulation of data.

\section{RESULTS}

\section{Distribution AND ABUNDANCE}

From 2009 to 2011, the Ring-billed Gull and California Gull bred at sites scattered over much of the western United States (Figures 2 and 3). Not only did the range of the California Gull extend farther south than that of the Ring-billed, but its largest colonies were near the southern end of its range, versus the opposite for the Ring-billed. For the Ring-billed Gull, we estimated about 87,995 adults were breeding at 36 colony sites across 7 of the 11 western states surveyed (Table 1). Of the total, $>90 \%$ were in four states: Washington (47.4\%), Montana (15.6\%), California (15.5\%), and Idaho (12.9\%) (Table 1). For the California Gull, we estimated 334,824 adults were breeding at 50 sites across 9 of the 11 western states (Table 2). Of the total, about $90 \%$ were breeding in four states: Utah (39.5\%), California (29.7\%), Washington (13.2\%), and Idaho (7.8\%) (Table 2). Just three colony sites-Great Salt Lake in Utah and Mono Lake and San Francisco Bay in California-accounted for about $64 \%$ of the 11-state total.

\section{DISCUSSION}

\section{POPUlATION TRENDS AND VARIABILITY}

Conover (1983) reported a substantial increase in the numbers of breeding Ring-billed and California gulls in the western United States from the 1920s through the 1970s, which he attributed to an increase in nesting sites at newly created reservoirs and expanded opportunities for foraging at garbage dumps and in irrigated agricultural fields. This population trend should be viewed with caution, however, because of limitations of data collection and observer coverage over that period (Shuford and Ryan 2000:159-161). Also, the trend might reflect in part a rebound from prior declines from human persecution and loss of wetlands. The five states that currently hold the largest numbers of gulls in the West (Tables 1 and 2) all lost substantial wetland acreage through the 1980s: California (91\% loss), Idaho (56\%), Washington (31\%), Utah (30\%), and Montana (27\%) (Dahl 1990).

In the nine western states surveyed in both periods, our estimates of 87,995 breeding Ringbilled Gulls and 334,824 California Gulls in 2009-2011 compare to estimates of 84,089 and 262,473 for these species, respectively, from 1976 to 1982 (Conover 1983). The earlier period's totals were adjusted to exclude the estimates of Ring-billed and California gulls from North and South Dakota (combined), states not surveyed from 2009 to 2011 (see Methods).

Despite the higher totals for both species in the more recent period, these differences are hard to interpret given the surveys' limitations, particularly in the earlier period (see below), and the large fluctuations in gull numbers over short periods of extreme environmental variability. The relatively small difference in Ring-billed Gull numbers suggests that the regional population has changed little in the last 30 years or so. While California Gull numbers may have increased over this period, perhaps fueled by the large increase in numbers in San Francisco Bay, estimates for the two largest interior colonies (Mono Lake, California, and Great Salt Lake, Utah), which account for a large proportion of the overall total, are not strictly comparable across the two periods.

At Mono Lake, standardized annual monitoring did not begin until 1983, when the total was about 5000 more gulls $(45,116$; Point Blue unpubl. data) than Conover (1983) reported in $1980(40,217)$, a difference that more likely represents the implementation of more robust survey methods in 1983 than year-to-year variation. For the period 1983-2015, the population of California Gulls nesting at Mono Lake has averaged 46,395 adults (range 33,548-64,976) (Point Blue unpubl. data). Although there has been a small but significant decline in numbers of nesting gulls over these 33 years $(\beta=-308.9, \beta \mathrm{SE}=$ $130.0, r^{2}=0.15, p=0.02$ ), this trend is driven in large part by four years in the early 1990s when, for unknown reasons, the population exceeded 


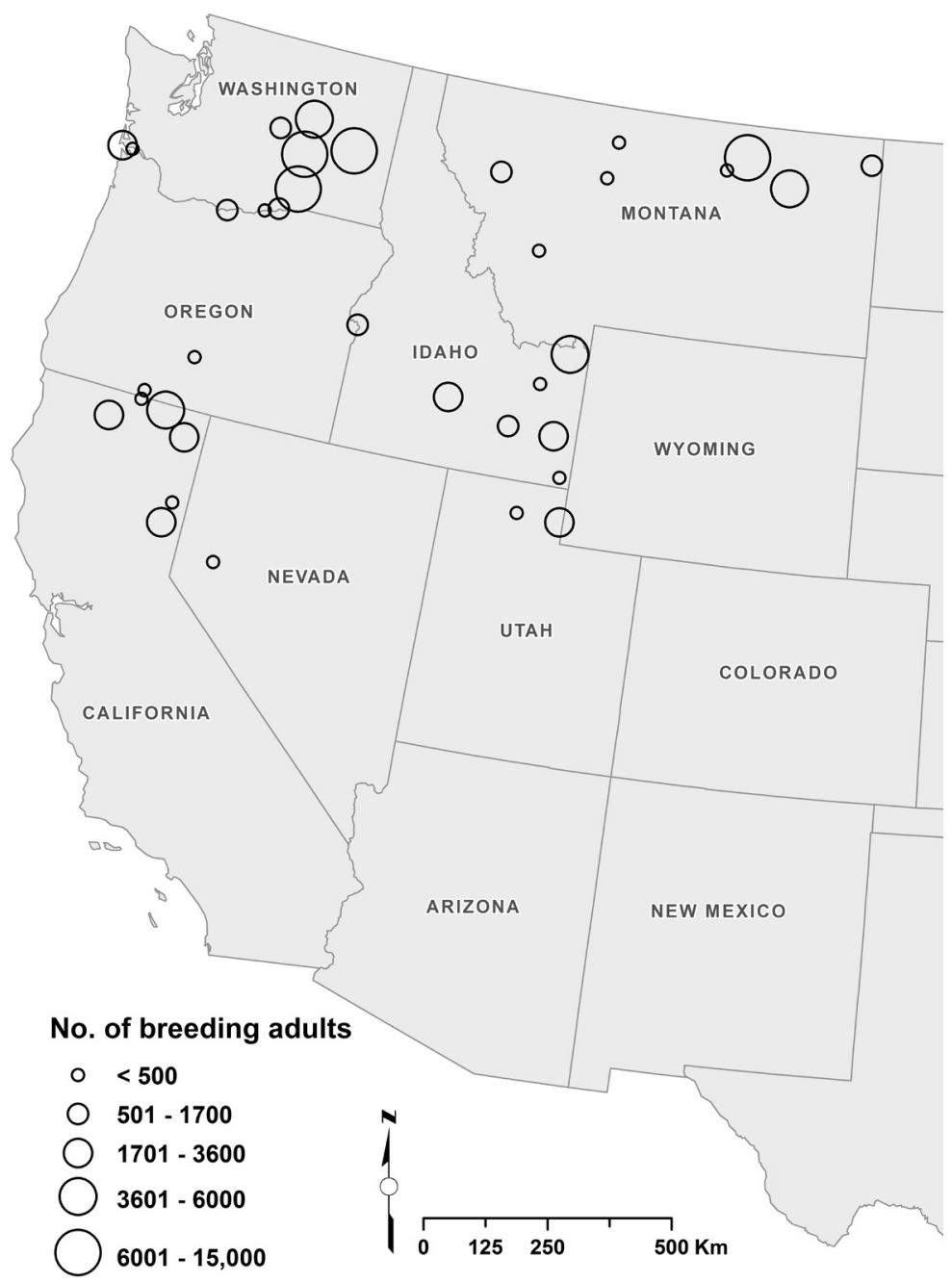

FIGURE 2. Distribution and relative size of Ring-billed Gull colonies from a survey of the interior of the western United States, 2009-2011, with supplemental data from coastal colonies in Oregon.

60,000 gulls. Over the last 10 years, the population has averaged 41,487 ( \pm SD 5017) adults.

At Great Salt Lake, the size of the California Gull population prior to the 1980 s was difficult to estimate because of sporadic records and unequal effort, but standardized surveys in the 1980s showed a relatively stable population of 75,000 to 80,000 breeding California Gulls (Paul et al. 1990). Note, however, that the estimate of about 50,000 adults in 1982 , used by Conover (1983), was considered by Paul et al. (1990) to be anomalous, indicating the temporary abandonment of a key nesting island. During the 1980s, numbers of gulls nesting at various sites within the Great Salt Lake fluctuated greatly in response to fluctuations in the lake's level (Paul et al. 1990).
In the early 1990 s, numbers continued to vary substantially at individual sites while the lakewide population increased dramatically (Robinette et al. 1993). The lake's overall population increased from an average of 78,067 ( \pm SD 1616, range 76,470-80,237) California Gulls for four years with surveys from 1983 to 1989 to 145,801 ( \pm SD 9524, range $133,965-156,071)$ in the four years from 1990 to 1993.

The dramatic change in the numbers of gulls nesting at Great Salt Lake between the two periods likely reflected large changes in the availability of suitable gull-nesting habitat and invertebrate food sources over a 10-year period of extreme environmental variability. From a low of about $1280 \mathrm{~m}$ $(4200 \mathrm{ft})$ above sea level in 1983, the elevation of 


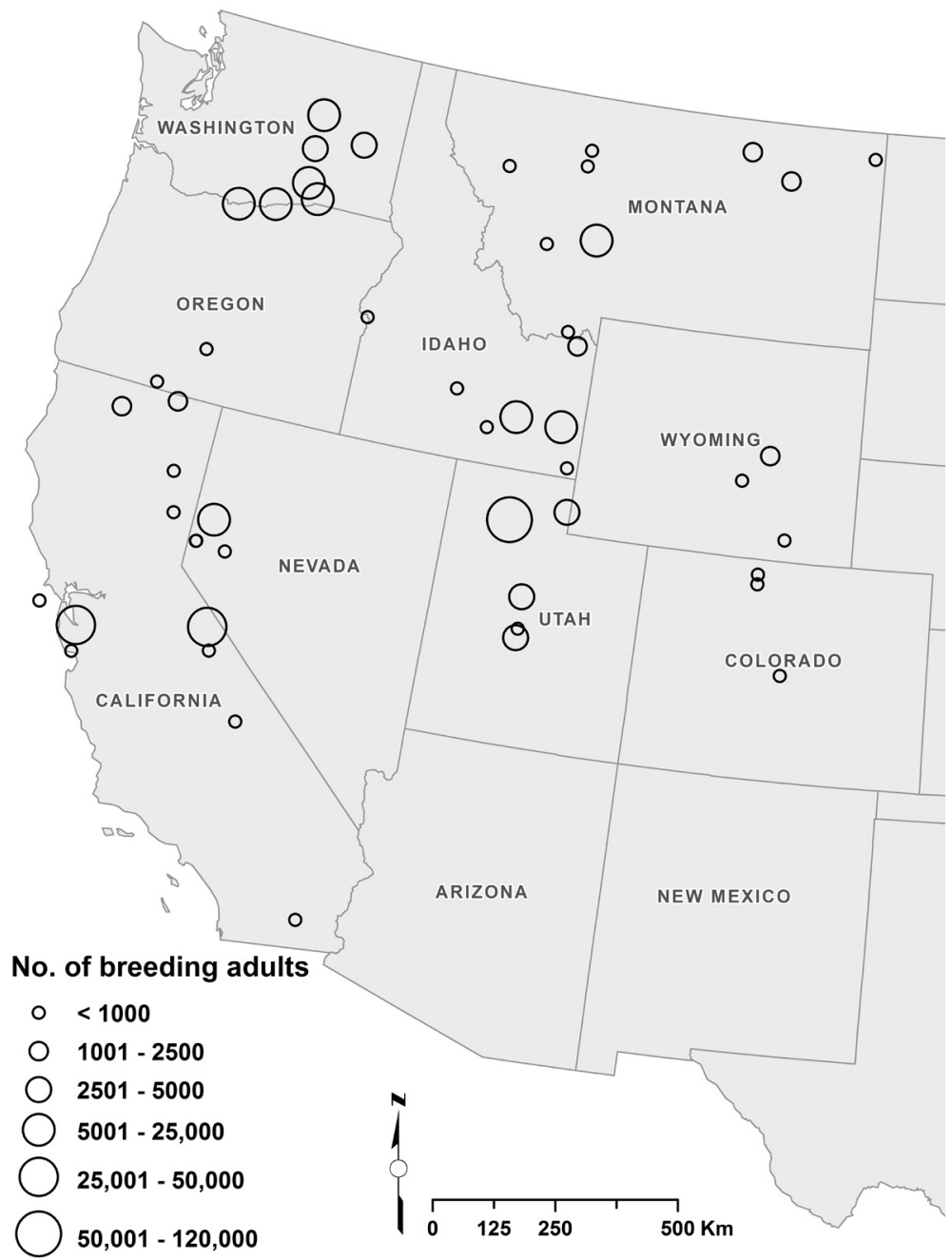

FIGURE 3. Distribution and relative size of California Gull colonies from a survey of the interior of the western United States, 2009-2011, with supplemental data from coastal colonies in California.

Great Salt Lake rose rapidly by $3.61 \mathrm{~m}(11.85 \mathrm{ft})$ to an historic high of $1283.77 \mathrm{~m}(4211.85 \mathrm{ft})$ in 1987, then declined quickly by the same amount

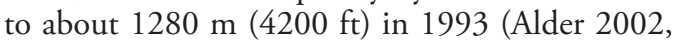
Austin 2002). During the periods of rising and falling lake level large areas were inundated then exposed (Zastrow and Ridd 2002), greatly reducing then greatly increasing the availability of habitat suitable for nesting gulls (J. Neill and D. Paul pers. comm.). On the decline, exposed areas were devoid of vegetation after extended inundation and so to California Gulls' liking. Concurrently, populations of the brine shrimp Artemia franciscana, a key food of gulls (Roberts 2013), decreased during a period of lowered salinity in the mid1980 s as the lake's level reached its maximum. By
1990 the shrimp had increased again as the falling lake's salinity rose. The fluctuation was likely a response to the increase then decline of other macroinvertebrates that prey on Artemia (Wurtsbaugh 1992, Wurtsbaugh and Smith Berry 1990).

As the estimates Conover (1983) reported for Mono Lake and Great Salt Lake appear to be lower than those from standardized surveys in subsequent years, his overall estimate for the western United States appears to be biased low. This and the substantial fluctuations, particularly at Great Salt Lake, makes it very difficult to interpret changes in the California Gull population in the West from the 1980s to the present. Apparent differences might reflect large changes in distribution, or variation in the proportion of adults 
TABLE 1. Estimated numbers of breeding Ring-billed Gulls from a survey of the interior of the western United States, 2009-2011, with comparisons to prior estimates, 1976-1982, and supplemental data from coastal colonies in Oregon ${ }^{a}$.

\begin{tabular}{|c|c|c|c|c|c|}
\hline \multirow[b]{2}{*}{ Site name (county) } & \multicolumn{3}{|c|}{ 2009-2011 } & \multicolumn{2}{|c|}{$1976-1982$} \\
\hline & Survey date & $\begin{array}{l}\text { No. breeding } \\
\text { birds }^{b}\end{array}$ & $\begin{array}{l}\text { Survey } \\
\text { method }^{c}\end{array}$ & $\begin{array}{c}\text { Survey } \\
\text { year }\end{array}$ & $\begin{array}{l}\text { No. breeding } \\
\text { birds }\end{array}$ \\
\hline \multicolumn{6}{|l|}{ Washington $^{d}$} \\
\hline Banks Lake (Grant) & 18 May 2009 & $4030^{3}$ & $\mathrm{AP}$ & 1977 & 5436 \\
\hline Sprague Lake (Adams) & 18 May 2009 & $6335^{3}$ & $\mathrm{AP}$ & 1977 & 1702 \\
\hline Potholes Reservoir (Grant) & 18 May 2009 & $14,826^{3}$ & $\mathrm{AP}$ & 1977 & 2292 \\
\hline Columbia River, Cabin Island (Grant) & 14 May 2009 & 0 & A & 1977 & 250 \\
\hline Columbia River, Island 18 (Franklin) & 15 May 2009 & 0 & A & 1977 & $4492^{e}$ \\
\hline Columbia River, Island 20 (Benton) & 18 May 2009 & $13,214^{3}$ & $\mathrm{AP}$ & - & - \\
\hline Columbia River, Richland (Franklin) $f$ & 15 May 2009 & $?$ & A & 1977 & $4710^{e}$ \\
\hline Columbia River, Miller Rocks (Klickitat) & 18 May 2009 & $1046^{3}$ & $\mathrm{AP}$ & 1977 & $60^{e}$ \\
\hline Columbia River, Blalock Island (Benton) & 5 June 2009 & $972^{3}$ & $\mathrm{AP}$ & - & - \\
\hline Columbia River, Rock Island (Benton) & 18 May 2009 & $1322^{3}$ & $\mathrm{AP}$ & - & - \\
\hline Whitcomb Island (Grays Harbor) $g$ & 18 June 2009 & 0 & A & 1976 & 4 \\
\hline Willapa Bay (Pacific)g & 18 June 2009 & 0 & A & 1976 & 40 \\
\hline Subtotal & & 41,745 & & & \\
\hline \multicolumn{6}{|l|}{ Oregond $^{d}$} \\
\hline $\begin{array}{l}\text { Columbia River, East Sand Island } \\
\text { (Clatsop })^{g}\end{array}$ & 8 June 2009 & $3146^{3}$ & $\mathrm{AP}$ & - & - \\
\hline Columbia River, Rice Island (Clatsop) ${ }^{g}$ & 8 June 2009 & $432^{3}$ & $\mathrm{AP}$ & - & - \\
\hline $\begin{array}{l}\text { Columbia River, Threemile Canyon } \\
\text { Island (Morrow) }\end{array}$ & 18 May 2009 & $412^{3}$ & $\mathrm{AP}$ & 1977 & 4380 \\
\hline Baker Sewage Lagoons (Baker) & - & 0 & I & ? & "breeding" \\
\hline Pelican Lake, Warner Valley (Lake) & 16 May 2009 & 0 & $\mathrm{C}$ & ? & 400 \\
\hline Summer Lake (Lake) & 19 June 2009 & $316^{1}$ & $\mathrm{O}$ & ? & 90 \\
\hline Upper Klamath Lake (Klamath) & 12 May 2009 & 0 & A & 1979 & "breeding"h \\
\hline $\begin{array}{l}\text { Noonan South Walking Wetland } \\
\text { (Klamath) }\end{array}$ & 10 June 2009 & $96^{1}$ & $\mathrm{O}$ & - & - $^{\circ}$ \\
\hline Swan Lake (Klamath) & 25 May 2009 & $0^{i}$ & $\mathrm{C}$ & - & - \\
\hline Subtotal & & 4402 & & & \\
\hline \multicolumn{6}{|l|}{ California } \\
\hline Lake Shastina (Siskiyou) & 13 May 2009 & $3178^{1}$ & $\mathrm{C}$ & - & - \\
\hline Lower Klamath NWR (Siskiyou) & 18 May 2009 & $232^{1}$ & $\mathrm{C}$ & 1980 & - \\
\hline Tule Lake NWR (Siskiyou/Modoc) & 12 May 2009 & 0 & $\mathrm{~A}, \mathrm{C}$ & 1976 & $0^{j}$ \\
\hline Clear Lake NWR (Modoc) & 18 May 2009 & $5452^{3}$ & $\mathrm{~B}$ & $?$ & "breeding" \\
\hline Goose Lake (Modoc) & $\begin{array}{c}\text { 16-17 May } \\
2009 \\
\end{array}$ & 0 & $\mathrm{O}$ & 1977 & $0^{k}$ \\
\hline
\end{tabular}

breeding in a given year, rather than changes in the species' overall population.

\section{SURVEY LIMITATIONS}

Conover's (1983) assessment was a compilation of available information rather than an attempt at a comprehensive, rangewide inventory (unlike the current effort), so its accuracy suffered for various reasons. An important limitation is incomplete or unequal coverage. For example, Conover (1983) reported California Gulls only as "breeding" at two sites in Wyoming in unspecified years. By contrast, Findholt (1986a) surveyed for California Gull colonies in Wyoming comprehensively in
1983 and 1984 and found breeding at six sites totaling 7273 nests (14,546 breeding adults). Similarly, Conover (1983) reported only six gull colonies from the interior of California from 1976 to 1980, but Shuford and Ryan (2000) noted that 14 colonies had been active in that area, at least intermittently, from 1994 to 1997. Commenting on populations of the California Gull at Great Salt Lake, Paul et al. (1990) noted that "sporadic records and unequal effort make data difficult to interpret." The same could be said for most sites across the range of both species in the western United States. Additional factors in Conover's (1983) assessment that compound 
TABle 1 (continued).

\begin{tabular}{|c|c|c|c|c|c|}
\hline \multirow[b]{2}{*}{ Site name (county) } & \multicolumn{3}{|c|}{ 2009-2011 } & \multicolumn{2}{|c|}{$1976-1982$} \\
\hline & Survey date & $\begin{array}{l}\text { No. breeding } \\
\text { birds }^{b}\end{array}$ & $\begin{array}{l}\text { Survey } \\
\text { method }^{c}\end{array}$ & $\begin{array}{l}\text { Survey } \\
\text { year }\end{array}$ & $\begin{array}{l}\text { No. breeding } \\
\text { birds }\end{array}$ \\
\hline Modoc NWR (Modoc) & 16 May 2009 & $1972^{1}$ & $\mathrm{C}$ & - & - \\
\hline Eagle Lake (Lassen) & 21 May 2009 & 0 & $\mathrm{C}$ & - & - \\
\hline Honey Lake WA (Lassen) & 14 May 2009 & 6 & $\mathrm{C}$ & 1977 & $100^{j}$ \\
\hline Lake Davis (Plumas) & 15 May 2009 & $2768^{1}$ & $\mathrm{C}$ & - & - \\
\hline Subtotal & & 13,608 & & & \\
\hline \multicolumn{6}{|l|}{ Nevada } \\
\hline Lahontan Reservoir (Churchill/Lyons) & 29 May 2009 & $316^{1}$ & $\mathrm{~B}$ & ? & - \\
\hline Subtotal & & 316 & & & \\
\hline \multicolumn{6}{|l|}{ Idaho } \\
\hline Snake River, Smith Island (Washington) & 5 June 2009 & $616^{1}$ & $\mathrm{C}$ & 1980 & 2000 \\
\hline Magic Reservoir (Blaine) & 3 June 2009 & $2930^{1}$ & $\mathrm{C}$ & 1978 & - \\
\hline Walcott (Blaine/Cassia) & 3 June 2009 & 0 & $\mathrm{C}$ & 1979 & - \\
\hline American Falls Reservoir (Bingham) & 1 June 2009 & $1284^{1}$ & $\mathrm{C}$ & 1979 & 12,000 \\
\hline Market Lake (Jefferson) & 3 June 2009 & $14^{1}$ & $\mathrm{O}$ & 1979 & "deserted" \\
\hline Mud Lake (Jefferson) & - & 0 & $\mathrm{I}$ & 1979 & 600 \\
\hline Island Park Reservoir (Fremont) & 5 June 2009 & $3604^{1}$ & $\mathrm{C}$ & 1979 & - \\
\hline Blackfoot Reservoir (Caribou) & 2 June 2009 & $2706^{1}$ & $\mathrm{C}$ & 1979 & 1000 \\
\hline Bear Lake NWR (Bear Lake) & 1 June 2009 & $224^{1}$ & $\mathrm{C}$ & 1979 & - \\
\hline Twin Lakes Reservoir (Camas) & - & 0 & $\mathrm{I}$ & $?$ & 3400 \\
\hline Couer d'Alene (Kootenai) & - & 0 & I & 1977 & 40 \\
\hline Subtotal & & 11,378 & & & \\
\hline \multicolumn{6}{|l|}{ Montana } \\
\hline Ninepipe NWR (Lake) & 15 June 2010 & $1406^{4}$ & $\mathrm{O}$ & ? & 225 \\
\hline Alkali Lake (Pondera) & - & $?$ & NS & 1976 & "breeding" \\
\hline Arod Lakes WPA (Teton) & 15 June 2010 & $0^{3}$ & $\mathrm{O}$ & $?$ & "breeding" \\
\hline Freezout Lake WMA (Teton) & 10 June 2009 & $0^{1}$ & $\mathrm{C}$ & 1980 & 2000 \\
\hline Tiber Resv/Lake Ewell (Liberty) & 16 June 2009 & $281^{4}$ & $\mathrm{~B}$ & ? & - \\
\hline Benton Lake (Cascade) & 17 June 2009 & "breeding" & NS & 1980 & - \\
\hline $\begin{array}{l}\text { Wild Horse Reservoir and Marsh } \\
\text { (Phillips) }\end{array}$ & 27 June 2009 & $276^{4}$ & $\mathrm{~B}$ & - & - \\
\hline Lake Bowdoin (Phillips) & 9 June 2009 & $7038^{1}$ & $\mathrm{U}$ & ? & "breeding" \\
\hline Fort Peck Lake (Valley/Garfield) & 21 June 2011 & $3657^{4}$ & $\mathrm{C}$ & ? & $2025^{l}$ \\
\hline Medicine Lake NWR (Sheridan) ${ }^{m}$ & 29 May 2009 & $704^{1}$ & $\mathrm{C}$ & 1980 & "breeding" \\
\hline $\begin{array}{l}\text { Warm Springs Ponds WMA (Deer } \\
\text { Lodge) }\end{array}$ & 12 June 2009 & $422^{4}$ & $\mathrm{~B}$ & - & - \\
\hline
\end{tabular}

(continued)

issues of variable coverage include summing data for multiple sites surveyed across years of widely varying environmental conditions, applying the mean size of colonies with counts to the many sites where gulls were reported only as "breeding," and not adjusting for adults away from the colony at sites with just rough estimates of breeding adults or pairs. Collectively these issues make interpretation of compiled data difficult except in cases when changes in numbers or distribution are very large.

Our 2009-2011 surveys also have their shortcomings. Key among these was surveying different sites in different years, particularly during a period of great annual variation in the amount of precipitation and surface water. Greater standardization of survey methods of the highest accuracy across all sites would also have been valuable. Given that surveying adults rather than nests was the best method at many locations, it would have been valuable to sample the ratio of adults to nests at more sites to generate a more robust correction for adults away from the colony at the time of surveys. Additionally, some historical gull colonies were not surveyed, and we likely missed a few recently established ones. For these reasons, our surveys yielded minimum estimates of the numbers of Ring-billed and California gulls breeding in the 11 
TABLE 1 (continued).

\begin{tabular}{|c|c|c|c|c|c|}
\hline \multirow[b]{2}{*}{ Site name (county) } & \multicolumn{3}{|c|}{ 2009-2011 } & \multicolumn{2}{|c|}{ 1976-1982 } \\
\hline & Survey date & $\begin{array}{l}\text { No. breeding } \\
\text { birds }^{b}\end{array}$ & $\begin{array}{c}\text { Survey } \\
\text { method }^{c}\end{array}$ & $\begin{array}{l}\text { Survey } \\
\text { year }\end{array}$ & $\begin{array}{c}\text { No. breeding } \\
\text { birds }\end{array}$ \\
\hline Yellow Water Reservoir (Petroleum) & - & ? & NS & ? & 200 \\
\hline Mason Lake (Musselshell) & - & ? & NS & ? & "breeding" \\
\hline Subtotal & & 13,734 & & & \\
\hline \multicolumn{6}{|l|}{ Utah } \\
\hline Great Salt Lake (Box Elder) & 31 May 2010 & $176^{1}$ & $\mathrm{C}$ & 1982 & - \\
\hline Neponset Reservoir (Rich) & 2 June 2010 & $2636^{1}$ & B & 1982 & - \\
\hline Subtotal & & 2812 & & & \\
\hline \multicolumn{6}{|l|}{ Wyoming } \\
\hline Yellowstone Lake (Teton) & summers & 0 & $\mathrm{AP}$ & $?$ & "breeding"n \\
\hline Torrington (Goshen) & 2009-2011 & ? & NS & ? & "breeding"n \\
\hline Bamforth Lake (Albany) & 30 June 2009 & 0 & $\mathrm{O}$ & $?$ & "breeding"n \\
\hline Subtotal & & 0 & & & \\
\hline Total & & 87,995 & & & \\
\hline
\end{tabular}

${ }^{a}$ Data for 1976-1982 from Conover (1983) unless otherwise indicated. Although not stated specifically by Conover (1983), dashes (-) for breeding status, transferred to this table, are assumed to indicate no breeding birds present.

${ }^{b}$ Methods used to derive numbers of breeding gulls: ${ }^{1}$ direct count of nests in the colony or count of incubating gulls from outside the colony (number of breeding birds $=$ nest count $\times 2$ ), ${ }^{2}$ count of nests from aerial photographs (number of breeding birds $=$ nest count $\times 2$ ), ${ }^{3}$ count of individual adult gulls on breeding colonies from aerial photographs, and ${ }^{4}$ count (may be rough) or estimate of adults from nonaerial method. As many breeding adults are away from the colony at any time, results of methods that yield counts of adults only are adjusted upward to estimate the number of breeding birds, on the basis of the ratio of adults sitting on nests to total adults visible in aerial photos taken at an oblique angle of colonies in Washington and Oregon from 2007 to 2010 (Bird Research Northwest unpubl. data; see Methods).

'Survey methods: A, aerial; AP, aerial photography; B, boat; C, ground survey in colony; D, distant vantage point; I, colony inactive because of lack of nesting islands or no nesting in region in recent years; NS, not surveyed and colony status uncertain; O, overview vantage point; and $U$, unknown method.

${ }^{d}$ For Washington and Oregon, most estimates in 2009 are from aerial surveys by Bird Research Northwest. Numbers for most active colonies are counts of adults at the colony site as assessed from high-resolution vertical photos (oblique photos at Blalock Is., Washington). These numbers were adjusted upward on the basis of the ratio of adults sitting on nests to total adults, as seen in photos (see footnote $b$ above and Methods). Inactive colonies were documented during aerial reconnaissance.

eThe numbers for Washington for 1977 in Conover (1983) are all attributed to Conover et al. (1979), yet for three colonies the numbers in the two papers differ substantially. Numbers in the 1979 and 1983 papers, respectively, are 960 and 60 for Miller Rocks, 678 and 4710 for Richland, and 1726 and 4492 for Island 18. We cannot explain the cumulative difference of 5898 birds between the two summaries.

fConover (1983) listed this site as "Richland," but there are several islands in the Columbia River near this town, none of which are so named on maps. Hence, this might be Island 18, 19, 20, or another island, but Island 20 was the only one occupied by gulls in 2009 (Bird Research Northwest in litt.).

gCoastal sites were not censused as part of the 11-state survey from 2009-2011, but data from coastal colonies for this and the prior period are included to enable a more comprehensive estimate of these states' breeding population.

bVarious authors have reported breeding Ring-billed Gulls at Upper Klamath Lake, but none appear to have identified a location or provided a numerical estimate of colonies there (see Shuford et al. 2006:29).

${ }^{i}$ An estimated 144 Ring-billed Gulls were at Swan Lake on 20 May 2009, but on a return visit to the island for a total nest count on 25 May observers found no gulls but old empty nests, some broken eggshells, and canid tracks and scat (Klamath Bird Observatory unpubl. data). Evidence was inconclusive as to whether the colony was disrupted by predators or if nesting was not fully initiated.

${ }^{j}$ Reports of 11,818 and 160 nesting Ring-billed Gulls at Tule Lake and Honey Lake, respectively, in Conover (1983) are in error (see Shuford and Ryan 2000:147).

${ }^{k}$ A report of $<20$ Ring-billed Gulls breeding at Goose Lake in 1977 is in error (see Shuford and Ryan 2000:149.)

${ }^{l^{\prime} F o r ~ u n s p e c i f i e d ~ y e a r s, ~ C o n o v e r ~(1983) ~ r e p o r t e d ~} 500$ Ring-billed Gulls at Gull and York islands, and 1525 at Beaver Island. It is unclear, however, if these should be added (as done here) or if the counts were in different years when different islands were occupied.

mIn 2009, water was low at Katy Lake and no colony was active, but at Medicine Lake, besides the colony that was counted, Ring-billed Gulls nested on three islands at the west end of the lake that were not counted. Although also not counted in 2010 and 2011 , the 3 -island colony was thought to have between 600 and 1500 nests (1200-3000 nesting gulls) in 2011 .

${ }^{n}$ During comprehensive surveys in 1983 and 1984, Findholt (1986b) did not find evidence for the four recent Ring-billed Gull colonies Conover (1983) listed for Wyoming, including these three and Seedskadee NWR, where gulls were "probably breeding." 
TABLE 2. Estimated numbers of breeding California Gulls from a survey of the interior of the western United States, 2009-2011, with comparisons to prior estimates, mainly 1976-1982, and supplemental data from coastal colonies in California ${ }^{a}$.

\begin{tabular}{|c|c|c|c|c|c|}
\hline \multirow[b]{2}{*}{ Site name (county) } & \multicolumn{3}{|c|}{ 2009-2011 } & \multicolumn{2}{|c|}{ 1976-1982 } \\
\hline & Survey date & $\begin{array}{l}\text { No. breeding } \\
\text { birds }^{b}\end{array}$ & $\begin{array}{l}\text { Survey } \\
\text { method }^{c}\end{array}$ & $\begin{array}{l}\text { Survey } \\
\text { year }\end{array}$ & $\begin{array}{l}\text { No. breeding } \\
\text { birds }\end{array}$ \\
\hline \multicolumn{6}{|l|}{ Washington $^{d}$} \\
\hline Banks Lake (Grant) & 18 May 2009 & $5205^{3}$ & $\mathrm{AP}$ & 1977 & 1690 \\
\hline Sprague Lake (Adams) & 18 May 2009 & $2504^{3}$ & $\mathrm{AP}$ & 1977 & 428 \\
\hline Potholes Reservoir (Grant) & 18 May 2009 & $3455^{3}$ & $\mathrm{AP}$ & 1977 & 436 \\
\hline Columbia River, Cabin Island (Grant) & 14 May 2009 & 0 & A & 1977 & 4 \\
\hline Columbia River, Island 18 (Franklin) & 15 May 2009 & 0 & A & 1977 & $5910^{e}$ \\
\hline Columbia River, Island 20 (Benton) & 1 May 2009 & $13,852^{3}$ & $\mathrm{AP}$ & - & - \\
\hline Columbia River, Richland (Franklin) $f$ & & & & 1977 & $3600^{e}$ \\
\hline $\begin{array}{l}\text { Columbia River, Crescent Island (Walla } \\
\text { Walla) }\end{array}$ & 18 May 2009 & $11,943^{3}$ & $\mathrm{AP}$ & - & - \\
\hline $\begin{array}{l}\text { Columbia River, Miller Rocks } \\
\text { (Klickitat) }\end{array}$ & 18 May 2009 & $7343^{3}$ & $\mathrm{AP}$ & 1977 & $960^{e}$ \\
\hline $\begin{array}{l}\text { Columbia River, Little Memaloose } \\
\text { Island (Klickitat) }\end{array}$ & 14 May 2009 & 0 & A & 1977 & 856 \\
\hline Subtotal & & 44,302 & & & \\
\hline \multicolumn{6}{|l|}{ Oregond $^{d}$} \\
\hline $\begin{array}{l}\text { Columbia River, Threemile Canyon } \\
\text { Island (Morrow) }\end{array}$ & 18 May 2009 & $8173^{3}$ & $\mathrm{AP}$ & 1977 & 4380 \\
\hline Baker Sewage Lagoons (Baker) & - & 0 & I & ? & "breeding" \\
\hline Malheur Lake (Harney) & $\begin{array}{l}\text { 12-15 May } \\
2009\end{array}$ & 0 & $\mathrm{C}$ & - & - \\
\hline Pelican Lake, Warner Valley (Lake) & 16 May 2009 & 0 & $\mathrm{C}$ & ? & 400 \\
\hline Summer Lake (Lake) & 19 June 2009 & $22^{1}$ & $\mathrm{O}$ & ? & 601 \\
\hline Upper Klamath Lake (Klamath) & 12 May 2009 & 0 & A & 1979 & "breeding" $g$ \\
\hline $\begin{array}{l}\text { Noonan South Walking Wetland } \\
\text { (Klamath) }\end{array}$ & 10 June 2009 & $6^{1}$ & $\mathrm{O}$ & - & - \\
\hline Swan Lake (Klamath) & 25 May 2009 & $0^{h}$ & $\mathrm{C}$ & - & - \\
\hline Subtotal & & 8201 & & & \\
\hline \multicolumn{6}{|l|}{ California } \\
\hline Lake Shastina (Siskiyou) & 13 May 2009 & $2298^{1}$ & $\mathrm{C}$ & - & - \\
\hline Lower Klamath NWR (Siskiyou) & 18 May 2009 & 0 & $\mathrm{C}$ & 1980 & 4000 \\
\hline Tule Lake NWR (Siskiyou/Modoc) & 12 May 2009 & 0 & $A, C$ & 1976 & $0^{i}$ \\
\hline Clear Lake NWR (Modoc) & 18 May 2009 & $1036^{4}$ & B & $?$ & "breeding" \\
\hline
\end{tabular}

western states. Regardless, the 2009-2011 surveys form a good baseline against which future broadscale surveys of the abundance and distribution of these two gull species can be compared.

\section{Distributional CHANGeS}

Since the broad assessment of Conover (1983), the two gull species have colonized areas to the south of their former known ranges. Ring-billed Gulls were first discovered breeding in Nevada on Gull Island at Lahontan Reservoir in 1983, when an estimated 400 birds were nesting (Gubanich and Judd 1988). Those authors did not know if this species had occupied that island prior to 1983 , so it is possible that they bred at that site during
Conover's 1976-1982 assessment. Regardless, that colony increased to about 2000 adults in 1986 and 3000-4000 in 1987 (Gubanich and Judd 1988). An estimated 316 Ring-billed Gulls were nesting at Lahontan Reservoir in 2009 (Table 1). In northeastern Nevada, nesting by Ring-billed Gulls was suspected, but not confirmed, at South Fork Reservoir in 2011 (WCWS database) and at Franklin Lake in the Ruby Valley between 1997 and 2000 (Floyd et al. 2007).

Although the Lahontan Reservoir colony in Nevada has persisted, with fluctuating numbers, not all colonies that extend a species' range remain active over the long term. For example, Findholt (1986b) surveyed Wyoming for nesting 
TABLE 2 (continued).

\begin{tabular}{|c|c|c|c|c|c|}
\hline \multirow[b]{2}{*}{ Site name (county) } & \multicolumn{3}{|c|}{ 2009-2011 } & \multicolumn{2}{|c|}{$1976-1982$} \\
\hline & Survey date & $\begin{array}{l}\text { No. breeding } \\
\text { birds }^{b}\end{array}$ & $\begin{array}{l}\text { Survey } \\
\text { method }^{c}\end{array}$ & $\begin{array}{c}\text { Survey } \\
\text { year }\end{array}$ & $\begin{array}{c}\text { No. breeding } \\
\text { birds }\end{array}$ \\
\hline Goose Lake (Modoc) & $\begin{array}{l}\text { 16-17 May } \\
2009\end{array}$ & 0 & $\mathrm{O}$ & 1977 & 1205 \\
\hline Eagle Lake (Lassen) & 21 May 2009 & $2^{1}$ & $\mathrm{C}$ & - & - \\
\hline Honey Lake WA (Lassen) & 14 May 2009 & 0 & $\mathrm{C}$ & 1977 & 15 \\
\hline Lake Davis (Plumas) & 15 May 2009 & $784^{1}$ & $\mathrm{C}$ & - & - \\
\hline Mono Lake (Mono) & $\begin{array}{l}24-27 \text { May } \\
2009\end{array}$ & $47,532^{1}$ & $\mathrm{C}$ & 1980 & 40,217 \\
\hline Laurel Pond (Mono) & 28 May 2009 & $278^{1}$ & $\mathrm{C}$ & - & - \\
\hline Owens Lake (Inyo) & $\begin{array}{l}26-29 \text { May } \\
2009\end{array}$ & $634^{1}$ & $\mathrm{C}$ & - & - \\
\hline Salton Sea (Imperial) & $\begin{array}{l}18 \text { May, } 8 \text { June } \\
2009\end{array}$ & $116^{1}$ & $\mathrm{C}$ & - & - \\
\hline $\begin{array}{l}\text { Southeast Farallon Island (San } \\
\text { Francisco) }\end{array}$ & 10 June 2009 & $190^{1}$ & $\mathrm{O}$ & - & - \\
\hline $\begin{array}{l}\text { San Francisco Bay (Santa Clara, } \\
\text { Alameda, Contra Costa, and San } \\
\text { Francisco })^{j}\end{array}$ & $\begin{array}{l}\text { 4 May-9 June } \\
\text { (mostly 13-21 } \\
\text { May) 2009 }\end{array}$ & $46,694^{1}$ & $\mathrm{C}$ & - & - \\
\hline $\begin{array}{l}\text { Capitola Mall (Santa Cruz) }{ }^{j} \\
\text { Subtotal }\end{array}$ & 9 June 2009 & $\begin{array}{c}2^{2} \\
99,566\end{array}$ & $\mathrm{AP}$ & - & - \\
\hline \multicolumn{6}{|l|}{ Nevada } \\
\hline $\begin{array}{l}\text { Pyramid Lake, Anaho Island NWR } \\
\text { (Washoe) }\end{array}$ & 24 May 2009 & $7260^{1}$ & $\mathrm{O}, \mathrm{C}$ & 1980 & $2950^{k}$ \\
\hline Parklane Mall (Washoe) $^{l}$ & 20 June 2011 & $156^{1}$ & $\mathrm{O}$ & ? & ? \\
\hline Virginia Lake (Washoe) & 4 June 2009 & $80^{1}$ & $\mathrm{O}$ & ? & "breeding" $m$ \\
\hline Lahontan Reservoir (Churchill/Lyons) & 29 May 2009 & $760^{1}$ & B & ? & "breeding"n \\
\hline Stillwater NWR (Churchill) & 2009, 2011 & 0 & $\mathrm{U}$ & 1977 & $3400^{\circ}$ \\
\hline Truckee River (Washoe?) & & 0 & $\mathrm{U}$ & ? & "breeding" \\
\hline Washoe Lake (Washoe) & & 0 & $\mathrm{U}$ & $?$ & "breeding" $p$ \\
\hline Wild Horse Reservoir (Elko) & & ? & NS & ? & "breeding" \\
\hline Subtotal & & 8256 & & & \\
\hline \multicolumn{6}{|l|}{ Idaho } \\
\hline Snake River, Smith Island (Washington) & 5 June 2009 & $924^{1}$ & $\mathrm{C}$ & 1980 & 5000 \\
\hline Snake River, Barson Island (Payette) & - & 0 & $\mathrm{I} q$ & 1972 & 1000 \\
\hline Magic Reservoir (Blaine) & 3 June 2009 & $30^{1}$ & $\mathrm{C}$ & 1978 & 10,000 \\
\hline $\begin{array}{l}\text { Minidoka NWR, Lake Walcott } \\
\text { Reservoir (Blaine/Cassia) }\end{array}$ & 3 June 2009 & $532^{1}$ & $\mathrm{C}$ & 1979 & 1200 \\
\hline American Falls Reservoir (Bingham) & 1 June 2009 & $11,550^{1}$ & $\mathrm{C}$ & 1979 & 30,000 \\
\hline Mud Lake (Jefferson) & - & 0 & I & 1979 & $2000+$ \\
\hline
\end{tabular}

Ring-billed Gulls comprehensively in 1983 and 1984 and did not find evidence for the four recent colonies Conover (1983) listed for that state. He did find a Ring-billed colony of 70 nests (140 breeding adults) at Soda Lake, Natrona County, which represented the first documented breeding by that species in Wyoming in over 50 years; in 2009, no Ring-billed Gulls were found nesting in that state (Table 1). In Colorado, Ring-billed Gulls bred at San Luis Lakes in the late 1800s, but since then there has been no evidence of breeding in that state (Findholt 1986b, Kingery 1998; Table 1).

The range of the California Gull has expanded to the south and west since 1980, when the southernand westernmost colony of this species was at Mono Lake, California (Conover 1983, Shuford and Ryan 2000). Through 2009, six new sites had been occupied in California outside of the former range (Table 2): three of these are in the interior (Laurel Pond, Owens Lake, and Salton Sea) and three on the coast (San Francisco Bay, Southeast Farallon Island, and 
TABLE 2 (continued).

\begin{tabular}{|c|c|c|c|c|c|}
\hline \multirow[b]{2}{*}{ Site name (county) } & \multicolumn{3}{|c|}{$2009-2011$} & \multicolumn{2}{|c|}{$1976-1982$} \\
\hline & Survey date & $\begin{array}{l}\text { No. breeding } \\
\text { birds }^{b}\end{array}$ & $\begin{array}{l}\text { Survey } \\
\text { method }^{c}\end{array}$ & $\begin{array}{c}\text { Survey } \\
\text { year }\end{array}$ & $\begin{array}{l}\text { No. breeding } \\
\text { birds }\end{array}$ \\
\hline Island Park Reservoir (Fremont) & 5 June 2009 & $1544^{1}$ & $\mathrm{C}$ & 1979 & “deserted” \\
\hline Blackfoot Reservoir (Caribou) & 2 June 2009 & $10,822^{1}$ & $\mathrm{C}$ & 1979 & 10,000 \\
\hline Bear Lake NWR (Bear Lake) & 1 June 2009 & $678^{1}$ & $\mathrm{C}$ & 1979 & 600 \\
\hline Twin Lakes Reservoir (Camas) & - & 0 & I & $?$ & "breeding" \\
\hline Subtotal & & 26,080 & & & \\
\hline \multicolumn{6}{|l|}{ Montana } \\
\hline Ninepipe NWR (Lake) & 15 June 2010 & $696^{4}$ & $\mathrm{O}$ & ? & 100 \\
\hline Alkali Lake (Pondera) & & ? & NS & 1976 & "breeding" \\
\hline Arod Lakes WPA (Teton) & 15 June 2010 & $696^{4}$ & $\mathrm{O}$ & ? & "breeding" \\
\hline Freezout Lake WMA (Teton) & 10 June 2009 & $12^{1}$ & $\mathrm{C}$ & 1980 & 2000 \\
\hline Benton Lake (Cascade) & June 2009 & "breeding" & NS & 1980 & 736 \\
\hline Lake Bowdoin (Phillips) & 9 June 2009 & $1826^{1}$ & $\mathrm{C}$ & ? & "breeding" \\
\hline Fort Peck Lake (Garfield) & 22 June 2011 & $2006^{4}$ & $\mathrm{C}$ & ? & $500^{r}$ \\
\hline Medicine Lake NWR (Sheridan) & 29 May 2009 & $404^{1}$ & $\mathrm{C}$ & 1980 & "breeding" \\
\hline Canyon Ferry WMA (Broadwater) & 26 May 2010 & $6732^{1}$ & $\mathrm{C}$ & 1980 & 280 \\
\hline Mason Lake (Musselshell) & & ? & NS & ? & 200 \\
\hline Yellow Water Reservoir (Petroleum) & & $?$ & NS & ? & 200 \\
\hline $\begin{array}{l}\text { Warm Springs Ponds WMA (Deer } \\
\text { Lodge) }\end{array}$ & 29 June 2010 & $36^{1}$ & $\mathrm{O}$ & - & - \\
\hline Broadview Marsh (Yellowstone) & & ? & NS & 1979 & 50 \\
\hline Lima Reservoir (Beaverhead) & & ? & NS & 1980 & 400 \\
\hline Red Rock Lakes NWR (Beaverhead) & 22 June 2010 & $82^{1}$ & $\mathrm{C}$ & - & - \\
\hline Subtotal & & 12,490 & & & \\
\hline \multicolumn{6}{|l|}{ Utah } \\
\hline $\begin{array}{l}\text { Great Salt Lake (Box Elder, Davis, Salt } \\
\text { Lake, Tooele) }\end{array}$ & $\begin{array}{c}2009 \text { (part; 2-8 } \\
\text { June), 2010 } \\
\text { (most; 25-31 } \\
\text { May) }\end{array}$ & $119,398^{1,2,3}$ & $\mathrm{AP}, \mathrm{O}, \mathrm{C}$ & 1982 & 49,841 \\
\hline Utah Lake (Utah) & $\begin{array}{c}\text { summers } 2009 \text {, } \\
2010\end{array}$ & 0 & B & 1982 & 15,572 \\
\hline Neponset Reservoir (Rich) & 2 June 2010 & $3746^{1}$ & B & 1982 & 3680 \\
\hline Nephi Sewage Lagoons (Juab) & 23 June 2009 & $4178^{4}$ & $\mathrm{O}$ & - & - \\
\hline Gunnison Sewage Lagoons (Sanpete) & 24 May 2010 & $166^{1}$ & $\mathrm{C}$ & - & - \\
\hline Salina Sewage Lagoons (Sevier) & 24 May 2010 & $4875^{4}$ & $\mathrm{O}$ & - & - \\
\hline Subtotal & & 132,363 & & & \\
\hline
\end{tabular}

Capitola Mall) (Table 2). The southernmost colony currently is $600 \mathrm{~km}$ south-southeast of Mono Lake at the Salton Sea, where $2-4$ adults attempted to nest at the north end in 1996 and a viable colony was established at the south end in 1997 (Molina 2000; 116 adults in 2009, Table 2).

By far the largest relatively new California Gull colony is in San Francisco Bay, which became the species' first coastal colony when established in 1980 (Burns et al. 2018). By 2009, San Francisco Bay held 46,694 breeding adults, which in that year represented $98 \%$ of the collective total for the six recently established colonies in California outside the species' previous range (Table 2). This percentage was even higher from 2012 to 2014, as the San Francisco Bay colony reached a plateau of about 52,000-53,000 adults before declining to 38,040 adults in 2016 (Burns et al. 2018). The gulls' use of landfills and other anthropogenic food sources appears to be a major contributing factor to the species' exponential growth in this bay (Burns et al. 2018).

Some of the smaller recent colonies have been short lived or have had poor reproductive success. The colony at Owens Lake has produced few young since it was first established in 2004 
TABLE 2 (continued).

\begin{tabular}{|c|c|c|c|c|c|}
\hline \multirow[b]{2}{*}{ Site name (county) } & \multicolumn{3}{|c|}{$2009-2011$} & \multicolumn{2}{|c|}{$1976-1982$} \\
\hline & Survey date & $\begin{array}{c}\text { No. breeding } \\
\text { birds }^{b}\end{array}$ & $\begin{array}{l}\text { Survey } \\
\text { method }^{c}\end{array}$ & $\begin{array}{l}\text { Survey } \\
\text { year }\end{array}$ & $\begin{array}{c}\text { No. breeding } \\
\text { birds }\end{array}$ \\
\hline \multicolumn{6}{|l|}{ Wyoming } \\
\hline Yellowstone Lake (Teton) & $\begin{array}{c}\text { summers } \\
2009-2011\end{array}$ & 0 & $\mathrm{AP}$ & ? & "breeding" \\
\hline Soda Lake (Natrona) & 11 July 2009 & $1393^{4}$ & B & - & - \\
\hline Pathfinder Reservoir (Carbon) & 29 June 2011 & $139^{4}$ & $\mathrm{O}$ & - & - \\
\hline Bamforth Lake (Albany) & 30 June 2009 & $696^{4}$ & $\mathrm{O}$ & $?$ & "breeding" \\
\hline Subtotal & & 2228 & & & \\
\hline \multicolumn{6}{|l|}{ Colorado } \\
\hline Walden Reservoir (Jackson) & 12 June 2010 & $614^{1}$ & $\mathrm{O}$ & - & - \\
\hline MacFarlane Reservoir (Jackson) & 14 May 2010 & $28^{4}$ & $\mathrm{O}$ & - & - \\
\hline Elevenmile Canyon Reservoir (Park) & 21 June 2010 & $696^{4}$ & $\mathrm{D}$ & 1978 & 150 \\
\hline Riverside Reservoir (Weld) & & ? & NS & 1980 & 200 \\
\hline Antero Reservoir (Park) & 21 June 2010 & 0 & $\mathrm{D}$ & 1980 & 800 \\
\hline Subtotal & & 1338 & & & \\
\hline Total & & 334,824 & & & \\
\hline
\end{tabular}

${ }^{a}$ Data for the earlier period are from Conover (1983) unless otherwise indicated.

${ }^{b}$ Methods used to derive numbers of breeding gulls: ${ }^{1}$ direct count of nests in the colony or count of incubating gulls from outside the colony (number of. breeding birds $=$ nest count $\times 2$ ), ${ }^{2}$ count of nests from aerial photographs (number of breeding birds $=$ nest count $\times 2$ ), ${ }^{3}$ count of individual adult gulls on breeding colonies from aerial photographs, and ${ }^{4}$ count (may be rough) or estimate of adults present from non-aerial method. As many adults are away from the colony at any time, results of methods that yield counts of adults only are adjusted upward to estimate the number of breeding birds, on the basis of the ratio of adults sitting on nests to total adults visible in aerial photos taken at an oblique angle of colonies in Washington and Oregon from 2007 to 2010 (Bird Research Northwest unpubl. data; see Methods and exceptions for single colonies in California and Utah).

'Survey methods: A, aerial; AP, aerial photography; B, boat; C, ground survey in colony; D, distant vantage point; I, colony inactive because of lack of nesting islands or no nesting in region in recent years; NS, not surveyed and colony status uncertain; O, overview vantage point; $\mathrm{U}$, unknown method.

${ }^{d}$ For Washington and Oregon, most estimates in 2009 are from aerial surveys by Bird Research Northwest. Numbers for most active colonies are counts of adults at the colony site as assessed from high-resolution vertical photos. These numbers were adjusted upward on the basis of the ratio of adults sitting on nests to total adults, as seen in photos (see footnote $b$ above and Methods). Inactive colonies were documented during aerial reconnaissance.

'The numbers for Washington for 1977 in Conover (1983) are all attributed to Conover et al. (1979), yet for three colonies the numbers in the two papers differ substantially. Numbers in the 1979 and 1983 papers, respectively, are 60 and 960 for Miller Rocks, 772 and 3600 for Richland, and 426 and 5910 for Island 18. We cannot explain the cumulative difference of 9212 gulls between the two summaries.

fConover (1983) listed this site as "Richland," but there are several islands in the Columbia River near this town, none of which are so named on maps. Hence, this might be Island 18, 19, 20, or another island, but Island 20 was the only one occupied by gulls in 2009 (Bird Research Northwest in litt.).

\&Various authors have reported breeding by California Gulls at Upper Klamath Lake, but none appear to have identified a location or provided a numerical estimate of colonies there (see Shuford et al. 2006:29).

${ }^{h}$ An estimated 680 California Gulls were at Swan Lake on 20 May 2009, but on a return visit to the island for a total nest count on 25 May observers found no gulls but old empty nests, some broken eggshells, and canid tracks and scat (Klamath Bird Observatory unpubl. data). Evidence was inconclusive as to whether the colony was disrupted by predators or if nesting was not fully initiated.

${ }^{i}$ A report of 1980 California Gulls at Tule Lake in Conover (1983) is in error (see Shuford and Ryan 2000:147).

${ }^{j}$ Coastal sites were not censused as part of the 11 -state survey, but data from these are included to enable a more comprehensive estimate for these states' breeding population.

${ }^{k}$ For the same year, Yochem et al. (1991) cited an estimate of 3400 adults (2975 in 1979).

'Mall torn down and California Gulls nesting on gravel substrate in fenced vacant lot.

$m$ Virginia Lake may be synonymous with Conover's (1983) "Reno City Parks."

${ }^{n}$ Rough estimate of 3000 nests (6000 adults) from 1983 to 1985 (Yochem et al. 1991), but only 500 and $>400$ nests reported for 1986 and 1987, respectively (Alcorn 1988).

${ }^{o}$ Estimate derived from Yochem et al. (1991; nests $\left.\times 2\right)$.

PRoughly 500 pairs (1000 adults) bred from at least the 1960s through 1975, but after efforts to eradicate the colony began up to 50 pairs (100 adults) have nested (sporadically) "in recent years" (Yochem et al. 1991).

qWe have been unable to locate anyone with knowledge of a Barson Island on the Snake River, but California Gulls currently appear to be nesting along the Snake River only on Smith Island.

${ }^{r}$ California Gulls nesting on York and Gull islands in an unspecified year (Conover 1983). 
though gulls have nested in most if not all years through 2017 (Point Blue unpubl. data, D. House/Los Angeles Dept. Water and Power in litt.). Reproductive success at the Southeast Farallon Island colony, established in 2008, has also been poor because of predation by nesting Western Gulls (Larus occidentalis) (R. Bradley pers. comm.). The California Gull's status at the Capitola Mall after 2009 is unclear, as netting to discourage nesting (mainly by Western Gulls) was installed on the roof in 2010. Observations of California Gulls engaged in courtship at nearby Brown Bulb Ranch Marketplace in April 2012 were inconclusive (D. Suddjian fide J. Davis in litt.). Two other ephemeral colonies were discovered after 2009. A colony that formed at the Davis Wastewater Ponds, Yolo County, in 2010 was the first in the California's Central Valley in over 85 years (cf. with records in Shuford and Ryan 2000). From 76 nests (152 breeding adults) in 2010, the colony declined over the next two years and was abandoned in 2013; no young fledged in any year (E. Whisler in litt.). A pair nested on East Anacapa Island in the Channel Islands off southern California in 2012 (McCaskie and Garrett 2013) and hatched young that did not survive; an adult seen in the vicinity of the previous nesting site on 16 March 2013 and 18 April 2014 is the only other suggestion of nesting there (Paul Collins in litt.).

Elsewhere, the 2009-2011 surveys found California Gulls nesting at three sets of sewage lagoons in central Utah, but it is unclear when these colonies were established. Subsequently, a colony of 26 California Gulls discovered at Heron Lake, Rio Arriba County, New Mexico, in 2013 represented the first breeding recorded in that state (Howe and Williams 2014). It represents a $150-\mathrm{km}$ southward advancement in the Rocky Mountain region and makes it the next most southern breeding site for the species in the United States after the Salton Sea.

\section{AdDitional Trend Data}

There are few sources of long-term data on population trends of wetland birds across large geographic areas in the United States, and fewer still that include colonial species that nest in the interior. The only one that we know of that has data on trends in numbers of the Ring-billed and California gulls across most of their breeding ranges is the North American Breeding Bird Survey (Sauer et al. 2014). From 1966 to 2013, the Ring-billed increased significantly in the eastern BBS region (3.60\%/year) and Canada (2.43\%/year), but the trends for the western BBS Region, United States, and survey-wide were not significant. For the five western states with data adequate for analysis, Washington, California, Idaho, and Wyoming showed nonsignificant decreasing trends, while Montana showed a nonsignificant increasing trend. For the same period, the California Gull showed a nonsignificant decreasing trend for the western BBS region, United States, and survey-wide. For the seven western states with adequate data, the decreases in Oregon (-5.38\%/year), California (-5.13\%/year), Idaho (-7.53\%/year), and Wyoming (-7.09\%/ year) were significant, those in Washington and Montana were not. An increase in Utah (4.57\%/ year) was significant.

The BBS trends for these two gull species should be interpreted cautiously, however, because the BBS generally is inadequate for monitoring colonial waterbirds (Bystrak 1981, Robbins et al. 1986) and because of large differences between BBS trends and patterns shown by colony surveys. For example, BBS data suggest a significant decline of the California Gull in California from 1968 to 2013 (Sauer et al. 2014) while the number of adults breeding in San Francisco Bay increased from none in 1979 to over 50,000 by 2012 (Burns et al. 2018).

\section{DROUGHT EFFECTS}

The variable precipitation from 2009 to 2011two dry years followed by a wet one (Figure 1) —affected lake and reservoir levels, the extent of wetlands, and the availability of gull-nesting sites in much of the West. In the interior of California, reduced water levels in 2009 had a substantial effect on both the abundance and distribution of nesting Ring-billed and California gulls in comparison to a wetter period from 1994 to 1997 when gull colonies were also surveyed on a broad scale (Shuford and Ryan 2000; Shuford 2014, Table 10). In terms of abundance, the estimated total of 13,608 breeding Ring-billed Gulls in 2009 represents only $54-66 \%$ of the totals from 1994 to 1997 when all key colonies were surveyed. Likewise, the total of 4120 breeding California Gulls in 2009 in the same area represents only $36-59 \%$ of the totals for that region from 1994 to 1997.

There were similar effects on distribution. Of the five sites in this region that held $>2000$ nesting gulls in any year from 1994 to 1997 only one-Clear Lake NWR_-did so in 2009 (Shuford 
2014, Table 10). Water levels at Meiss Lake in Butte Valley Wildlife Area (WA), Goose Lake, Big Sage Reservoir, and Hartson Reservoir in Honey Lake WA were so low that all potential nesting islands were connected to the shoreline. Gulls failed to nest at all of these sites except at Honey Lake WA, where only 6 Ring-billed Gulls nested at an impoundment next to Hartson Reservoir. Conversely, in 2009 large colonies of gulls were active at two sites-Dorris Reservoir on Modoc NWR and Lake Davis - that were unoccupied from 1994 to 1997. Similarly, Lake Shastina held at most about 700 nesting gulls in previous years but over 5400 gulls in 2009. It seems likely that Dorris Reservoir absorbed gulls that might otherwise have nested relatively close by at either Goose Lake or Big Sage Reservoir, and the same may have been true for Lake Davis with respect to Honey Lake WA. Although water levels at Lake Shastina were also unusually low during the 2009 drought, the low water increased rather than reduced the lake's potential for gull nesting, as islands in deeper parts of the reservoir increased in size with the dropping level and were able to accommodate more nesting gulls on previously submerged substrate.

The effect of drought during the 2009-2011 survey period was also noticeable in Oregon. Low water at Swan Lake allowed canids (presumably coyotes) to reach nesting islands in May 2009, and gulls either abandoned their effort or failed to initiate nesting (Tables 1 and 2). Swan Lake held an estimated 13,208 and 2320 nesting Ringbilled and California gulls, respectively, in 2004 (Shuford et al. 2006). But that year it may have absorbed gulls from an often large colony at Meiss Lake, California, about $60 \mathrm{~km}$ to the southwest, where water levels were too low to maintain isolation of nesting islands.

Collectively, this information provides only a limited snapshot of colony dynamics between dry and wet periods. Over the short term, drought affects gull distribution by changing the availability of nesting habitat. Gull colonies on islands that become connected to the mainland typically fail once they are accessible to mammalian predators, though peninsular colonies sometimes persist if distant from source populations of predators (e.g., at Great Salt Lake; J. Neill pers. comm.). Conversely, islands that remain isolated and increase in size as water levels drop may attract more gulls. Yet the long-term effects of drought on the total population size of gulls are poorly understood.

\section{Future Climate Change}

Recently Langham et al. (2015) and Schuetz et al. (2015) modeled broad-scale changes in the distribution of North American bird species under various climate-change scenarios. They projected that by 2080 the summer and winter ranges of the California Gull will have shrunk by $91 \%$ and $45 \%$, respectively, whereas those of the Ringbilled Gull will have expanded by $43 \%$ and $32 \%$, respectively. Given that both of these gull species are generalists and opportunistic in their foraging habitats, often breed at the same sites, and overlap broadly over much of their ranges, it is unclear why the California Gull is projected to suffer severe range contractions and the Ring-billed Gull to enjoy substantial range expansions. Despite this, the authors' resulting summary report on birds and climate change (climate.audubon.org) considers both gull species to be threatened under projected climate-change scenarios.

\section{THREATS AND MANAGEMENT CONSIDERATIONS}

The greatest threat to gull colonies in the interior is the periodic absence or scarcity of nesting islands or sites (Shuford and Ryan 2000) that provide protection or isolation from terrestrial predators. These gull species are, of course, adapted to the periodic droughts that occur in the West, but there are limits to their adaptability. Increased human manipulation of water systems along with changing weather and climatic conditions are likely to increase the frequency of desiccation of foraging habitats and of predators' access to nesting islands (Shuford 2014). Because of vegetational succession, substrate suitable for gull nesting appears to be declining on some islands along the middle Columbia River, but this loss may be offset by accretion of sand and gravel at other locations (P. Loschl pers. comm.). Gulls also may be displaced from traditional nesting locations by human hazing to favor other more highly valued bird species (e.g., Burns et al. 2018). Habitat loss and degradation is a continuing threat that should be considered in management of these gulls, but the net effects of the types of habitat changes described above are unclear.

Conversely, gull populations increasing in response to human alteration of the landscape can affect other native bird species negatively. A prime example is the exponential increase of the California Gull population in San Francisco Bay. This large population poses substantial challenges for meeting the South Bay Salt Pond Restoration 
Project's (www.southbayrestoration.org) goals: to restore salt marsh for the endangered Ridgway's Rail (Rallus obsoletus obsoletus) and salt-marsh harvest mouse (Reithrodontomys raviventris) while maintaining or increasing populations of other breeding waterbirds and shorebirds as the extent of former salt ponds is reduced (Shuford 2008, Burns et al. 2018). Substantial gull predation has been documented on eggs and chicks of the Forster's Tern (Sterna forsteri), American Avocet (Recurvirostra americana), and Snowy Plover (Charadrius nivosus). The U.S. Fish and Wildlife Service has designated the coastal population of the plover as threatened. Although management of the gulls, particularly hazing at landfills, has been undertaken, whether it will be sufficient to reduce gull predation on these other species remains to be seen. Clearly, with the continuing human manipulation of the environment coupled with the unpredictable effects of climate change, balancing the needs of various wildlife species will be a challenge.

\section{FUTURE MONITORING}

Monitoring gulls and other colonial waterbirds in the West is complex. The degree of accuracy and repeatability of counts of such species varies greatly by species, sites, and habitat, and with the variation in time of onset of breeding (Conover 1983; Bibby et al. 2000; Shuford 2010, 2014). The accuracy of counts can also be affected by factors such as the size of a colony, the area to be searched, and the resources available to surveyors. Significantly, climatic variation can greatly affect habitat availability and hence the presence, size, and distribution of colonies over relatively short periods. To refine future efforts, much can be learned from Conover's (1983) compilation and the 2009-2011 gull inventory, but broad-scale attempts to survey all colonies over a large area are likely to be infrequent because of logistical and financial constraints. When they are undertaken, however, they should cover all colonies in the same year. If possible, follow-up surveys should be done in a year without extreme climatic conditions rather than scheduled solely on the basis of a fixed interval between surveys.

A more practical approach to monitoring the populations of the Ring-billed and California gulls across the western United States would be to implement a standardized method of surveying a subset of known or potential colony sites annually or at short intervals. Problems for designing a sampling scheme include the birds' clumping at widely scattered locations, the shifting of colonies in response to a fluctuating climate, habitat modifications, and human disturbance. Important considerations that should be incorporated in future monitoring include standardized survey methods, a statistically robust sampling framework, coordination to ensure consistency across all areas monitored, a centrally managed database with easy-to-use data-analysis tools, and institutional support for all partners that will last for many years (Steinkamp et al. 2003, Shuford 2014:49-51).

No matter what monitoring program is implemented, the design should enable the achievement of specific goals (Steinkamp et al. 2003). It is important to think beyond measuring change in numbers over time so that the information collected can be used effectively to evaluate management and in making decisions. Is the main objective to detect population declines that may require management to reverse, or is the main interest in documenting colony locations? Should selection of sites for sampling be entirely randomized or should it also include the largest sites and ones facing immediate threats? Whatever the initial method selected, it is likely that it will need to be refined on the basis of lessons learned during implementation or with the availability of new technology. The current experimentation with use of aerial drones for surveying wildlife (e.g., Ogden 2013) suggests that the way biologists monitor colonial waterbirds may change rapidly in coming years.

\section{ACKNOWLEDGMENTS}

We greatly appreciate the help of the many participants and collaborators in the WCWS, without which this paper would not have been possible. Special thanks also to Stephanie Jones, Bill Howe, Nanette Seto, and Jennifer Wheeler for their foresight and development of the WCWS. The large number of individuals and organizations who conducted surveys or provided valuable information to coordinators on the locations and status of waterbird colonies in the eight interior western states are listed in Appendix A of Cavitt et al. (2014). The numerous participants, collaborating agencies and organizations, and landowners who provided assistance in California are listed in the acknowledgments in Shuford (2014). Gull colonies in Washington and Oregon were surveyed by the biologists of Bird Research Northwest and Klamath Bird Observatory. Thanks to the following coordinators, surveyors, and local experts who answered questions about data quality and specific 
conditions during, or prior to, the period of the WCWS: Jennifer Ballard, Lisa Baril, Jason Beason, John Cavitt, Joe Gilbert, Jim Lawrence, Colleen Moulton, John Neill, Andrea Orabona, Don Paul, Larry Roberts, Steve Schafer, Steve Tessmann, and Catherine Wrightman. Russ Bradley, Phil Capitolo, Paul Collins, Liz Cruz, Debbie House, Pete Loschl, Michelle McDowell, Kathy Molina, Kristie Nelson, Adam Peck-Richardson, Dan Roby, Jaime Stephens, and Ed Whisler kindly shared observations or unpublished data from Washington, Oregon, and California. The manuscript was improved by thorough reviews by Bob Gill, Peter Loschl, and John Neill. Funding for the WCWS was provided by the U.S. Fish and Wildlife Service (regions 1, 2, 6, 8, and headquarters), American Bird Conservancy, California Rice Commission, Imperial Irrigation District, Pasadena Audubon Society, S. D. Bechtel, Jr. Foundation, Weber State University, and state natural resource or fish and wildlife agencies in the 11 western states. The findings and conclusions in this article are those of the authors and do not necessarily represent the views of the U.S. Fish and Wildlife Service. This is contribution 2049 of Point Blue Conservation Science.

\section{LiTERATURE CITED}

Alcorn, J. R. 1988. The Birds of Nevada. Fairview West, Fallon, NV.

Alder, W. 2002. The National Weather Service, weather across Utah in the 1980s, and its effect on Great Salt Lake, in Great Salt Lake: An overview of change (J. W. Gwynn, ed.), pp. 295-301. DNR Spec. Publ., Utah Geol. Surv., Utah Dept. Nat. Res., Salt Lake City.

Austin, L. H. 2002. Problems and management alternatives related to the selection and construction of the West Desert Pumping Project, in Great Salt Lake: An overview of change (J. W. Gwynn, ed.), pp. 303-312. DNR Spec. Publ., Utah Geol. Surv., Utah Dept. Nat. Res., Salt Lake City.

Bibby, C. J., Burgess, N. D., Hill, D. A., and Mustoe, S. 2000. Bird Census Techniques, 2nd ed. Academic Press, London.

Burns, C. E., Ackerman, J. T., Washburn, N. B., BlusoDemeres, J., Robinson-Nilsen, C., and Strong, C. 2018. California Gull population growth and ecological impacts in the San Francisco Bay estuary, 1980-2016, in Trends and traditions: Avifaunal change in western North America (W. D. Shuford, R. E. Gill Jr., and C. M. Handel, eds.), pp. 180-189. Studies of Western Birds 3. Western Field Ornithologists, Camarillo, CA; doi 10.21199/SWB3.9.

Bystrak, D. 1981. The North American Breeding Bird Survey. Studies Avian Biol. 6:34-41.
Cavitt, J. F., Jones, S. L., Wilson, N. M., Dieni, J. S., Zimmerman, T. S., Doster, R. H., and Howe, W. H. 2014. Atlas of breeding colonial waterbirds in the interior western United States. Research report, USDI, USFWS, Denver; www.fws.gov/mountain-prairie/ migbirds/species/birds/western_colonial/.

Conover, M. R. 1983. Recent changes in Ring-billed and California gull populations in the western United States. Wilson Bull. 95:362-383.

Conover, M. R., Thompson, B. C., Fitzner, R. E., and Miller, D. E. 1979. Increasing populations of Ringbilled and California gulls in Washington State. W. Birds 10:31-36.

Dahl, T. E. 1990. Wetlands losses in the United States, 1780 's to 1980 's. USDI, USFWS, Washington, DC.

Findholt, S. 1986a. Status and distribution of California Gull nesting colonies in Wyoming. Great Basin Nat. 46:128-133.

Findholt, S. L. 1986b. The Ring-billed Gull: A rediscovered nesting species in Wyoming. W. Birds 17:189190.

Floyd, T., Elphick, C. S., Chisholm, G., Mack, K., Elston, R. G., Ammon, E. M., and Boone, J. D. 2007. Atlas of the Breeding Birds of Nevada. Univ of Nevada Press, Reno and Las Vegas.

Gubanich, A. A., and Judd, H. 1988. First report of nesting Ring-billed Gulls in Nevada. W. Birds 19:125-127.

Howe, W. H., and Williams, S. O., III. 2014. First nesting of the California Gull in New Mexico. W. Birds 45:199-203.

Jones, S. L. 2008. Western Colonial Waterbird Survey protocols. Unpubl. rep., USDI, USFWS, Nongame Migratory Birds Coordinator's Office, Denver; www.fws.gov/mountain-prairie/migbirds/species/ birds/western_colonial/.

Kingery, H. E. (ed.). 1998. Colorado Breeding Bird Atlas. Colorado Bird Atlas Partnership and Colorado Div. Wildl.; www.cobreedingbirdatlasii.org/.

Langham, G. M., Schuetz, J. G., Distler, T., Soykan, C. U., and Wilsey, C. 2015. Conservation status of North American birds in the face of climate change. PLoS One 10(9): e0135350; doi 10.1371/journal. pone. 0135350 .

McCaskie, G., and Garrett, K. L. 2013. Southern California region. N. Am. Birds 66:732-736.

Molina, K. C. 2000. The recent nesting of California and Laughing gulls at the Salton Sea, California. W. Birds 31:106-111.

Ogden, L. E. 2013. Drone ecology. BioScience 63:776; doi 10.1525/bio.2013.63.9.18.

Paul, D. S., Jehl, J. R., Jr., and Yochem, P. K. 1990. California Gull populations nesting at Great Salt Lake, Utah. Great Basin Nat. 50:299-302.

Pollet, I. L., Shutler, D., Chardine, J., and Ryder, J. P. 2012. Ring-billed Gull (Larus delawarensis), in The Birds of North America Online (A. Poole, ed.), no. 33. Cornell Lab. Ornithol., Ithaca, NY; doi 10.2173/bna.33

Robbins, C. S., Bystrak, D., and Geissler, P. H. 1986. 
The Breeding Bird Survey: Its first fifteen years, 1965-1979. Resource Publ. 157, USDI, USFWS, Washington, DC.

Roberts, A. J. 2013. Avian diets in a saline ecosystem: Great Salt Lake, Utah, USA. Human-Wildl. Interactions 7:158-168.

Robinette, K. W., White, P. A., and Howe, F. P. 1993. 1993 Great Salt Lake California Gull survey. Unpubl. rep., available from Great Salt Lake Ecosystem Program, Utah Div. Wildl. Res., 4790 S 7500 W, Hooper, UT 84315.

Sauer, J. R., Hines, J. E., Fallon, J. E., Pardieck, K. L., Ziolkowski, D. J., Jr., and Link, W. A. 2014. The North American Breeding Bird Survey, results and analysis 1966-2013, version 01.30.2015. USGS Patuxent Wildl. Res. Ctr., Laurel, MD; www.mbrpwrc.usgs.gov/bbs/bbs.html.

Schuetz, J. G., Langham, G. M., Soykan, C. U., Wilsey, C. B., Auer, T., and Sanchez, C. C. 2015. Making spatial prioritizations robust to climate change uncertainties: A case study with North American birds. Ecol. Appl. 25:1819-1831; doi 10.1890/14-1903.1.

Seto, N. W. H. 2008. Coordinated colonial waterbird inventory and monitoring in the western United States: Comprehensive breeding season surveys. USDI, USFWS, Migratory Birds and Habitat Programs, Portland, OR; www.fws.gov/mountain-prairie/species/ birds/western_colonial/.

Shuford, W. D. 2008. A synthesis of information on California Gulls to further attainment of salt pond restoration goals in South San Francisco Bay. Report to the Coastal Conservancy Association and the South Bay Salt Pond Restoration Project. PRBO Conservation Science (Contrib. 1642), 3820 Cypress Dr. \#11, Petaluma, CA 94954; www.southbay restoration.org/documents/technical/.

Shuford, W. D. 2010. Inland-breeding pelicans, cormorants, gulls, and terns in California: A catalogue, digital atlas, and conservation tool. Wildl. Branch, Nongame Wildl. Progr. Rep. 2010-01. Calif. Dept. Fish and Game, Sacramento; nrm.dfg.ca.gov/FileHandler. ashx? DocumentID=24095.

Shuford, W. D. 2014. Patterns of distribution and abundance of breeding colonial waterbirds in the interior of California, 2009-2012. A report of Point Blue Conservation Science to Calif. Dept. Fish and Wildl. and USFWS (Region 8); www.fws.gov/ mountain-prairie/migbirds/species/birds/western colonial/.

Shuford, W. D., and Henderson, R. P. 2010. Surveys of colonial waterbirds in northeastern and east-central
California in 2009. Unpubl. rep., USFWS, Region 8, Sacramento, CA.

Shuford, W. D., and Ryan, T. P. 2000. Nesting populations of California and Ring-billed gulls in California: Recent surveys and historical status. W. Birds 31:133-164.

Shuford, W. D., Thompson, D. L., Mauser, D. M., and Beckstrand, J. 2006. Abundance and distribution of nongame waterbirds in the Klamath Basin of Oregon and California from comprehensive surveys in 2003 to 2004. Final Report to USFWS, Klamath Basin NWR Complex, 4009 Hill Rd., Tulelake, CA 96134. Contrib. 1284 of PRBO Conservation Science, 3820 Cypress Dr., \#11, Petaluma, CA 94954.

Steinkamp, M., Peterjohn, B., Byrd, V., Carter, H., and Lowe, R. 2003. Breeding season survey techniques for seabirds and colonial waterbirds throughout North America. Draft 13 February 2003; www. bu.edu/scscb/working_groups/resources/steinkampsurvey-techniques.pdf.

Strong, C. M., Spear, L. B., Ryan, T. P., and Dakin R. E. 2004. Forster's Tern, Caspian Tern, and California Gull colonies in San Francisco Bay: Habitat use, numbers, and trends, 1982-2003. Waterbirds 27:411423; doi 10.1675/1524-4695(2004)027[0411:FTCTAC]2.0.CO;2.

Winkler, D. W. 1996. California Gull (Larus californicus), in The Birds of North America Online (A. Poole, ed.), no. 259. Cornell Lab. Ornithol., Ithaca, NY; doi 10.2173/bna.259.

Winkler, D. W., and Shuford, W. D. 1988. Changes in the numbers and locations of California Gulls nesting at Mono Lake, California, in the period 1863-1986. Colon. Waterbirds 11:263-274; doi 10.2307/1521008.

Wurtsbaugh, W. A. 1992. Food-web modification by an invertebrate predator in the Great Salt Lake (USA). Oecologia 89:168-175; doi 10.1007/BF00317215.

Wurtsbaugh, W. A., and Smith Berry, T. 1990. Cascading effects of decreased salinity on the plankton, chemistry, and physics of the Great Salt Lake (Utah). Can. J. Fish. Aquat. Sci. 47:100-109; doi 10.1139/ f90-010.

Yochem, P. K., Jehl, J. R., Jr., Stewart, B. S., Thompson, S., and Neel, L. 1991. Distribution and history of California Gull colonies in Nevada. W. Birds 22:1-12.

Zastrow, L., and Ridd, M. 2002. Satellite imaging and analysis of Great Salt Lake, in Great Salt Lake: An overview of change (J. W. Gwynn, ed.), pp. 313324. DNR Spec. Publ., Utah Geol. Surv., Utah Dept. Nat. Res., Salt Lake City. 